\title{
Development of Print and Illustration Laboratories Using Creative Tools
}

\author{
Masnuna $^{1}$, Lily Syahrial², Dyan Agustin ${ }^{3}$ \\ ${ }^{1}$ Visual Communication Design/Faculty of Architecture and Design, UPN "Veteran" Jawa Timur, \\ Indonesia \\ ${ }^{2}$ Architecture/ Faculty of Architecture and Design, UPN "Veteran" Jawa Timur, Indonesia \\ ${ }^{3}$ Architecture/ Faculty of Architecture and Design, UPN "Veteran" Jawa Timur, Indonesia \\ Corresponding Author’s Email : masnuna.vcd@upnjatim.ac.id
}

\begin{abstract}
The Faculty of Architecture and Design is one of the faculties at UPN "Veteran" Jawa Timur, which consists of the Architecture Study Program and the Visual Communication Design (VCD) Study Program. Various teaching, research and service activities have been carried out by lecturers and students who are members of the laboratory. There are 4 laboratories incorporated in the VCD program, one of which is the Print and Illustration laboratory. Many products have been produced by this laboratory, including Visual Design and Souvenir Products, popup books, profile books, sign systems, illustration book, etc. However, there are few obstacles faced by print and illustration laboratories and several other laboratories, namely the lack of tools, facilities and infrastructure. There are currently several tools that are damaged and cannot function optimally. The tools needed are digital press machines, A3 printers, cameras, and display cabinets. With these tools, it can produce souvenir products as a promotional media, as well as a reminder (memento), which has artistic value in introducing the campus UPN "Veteran" Jawa Timur on a wider area. Among them were the cup package and profile book of UPN "Veteran" Jawa Timur. This research method outlines through two stages, namely: (1) the preparation phase; (2) the stage of creation. The preparation phase includes data collection, observation, and analysis. While the stages of creation include preproduction, production and post-production. With the existence of these production support tools, it is expected that laboratory performance will be more optimal and the products produced can be better and can be commercialized.
\end{abstract}

Keywords: souvenir, laboratory, print and illustration, UPN

\section{INTRODUCTION}

Faculty of Architecture and Design (FAD) is one of the faculties in UPN "Veteran" Jawa Timur, which consists of the Architecture Study Program and Visual Communication Design Study Program. As a new faculty in the ranks of UPN "Veteran" Jawa Timur, FAD has the duty and authority to preserve, develop, disseminate, and explore science, technology, and arts, as well as functions to develop the quality of human resources, both among teaching staff, education staff and students. In accordance with the vision of FAD, which is to become the Faculty of Architecture and Design which excellent and have state defense character and 
has the mission of organizing and developing engineering education and design with the state defense character and improving the culture of engineering research and design in the development of science and technology that are useful for the welfare of society, the presence of laboratories in FAD has a very important role urgent. Various teaching, research and service activities have been carried out by lecturers and students of the Visual Communication Design study program which are incorporated in the laboratory. There are 4 laboratories incorporated in the Visual Communication of Design program, including:

1. Print and Illustration Laboratory includes: product printing, screen printing, manual drawing, illustrations, comics, shapes drawing, sketches, packaging, pop-up books.

2. The Media Record Laboratory includes: photography, videography, audio visual, Television Commercial (TVC).

3. The Computer Graphics Laboratory includes: digital painting, animation, web design, graphic design, print advertising.

4. Design Laboratory includes: design concepts, design research methods.

The four laboratories support each other and are related in producing a product both from the results of the teaching and learning process and from the results of research. The products are expected to be commercialized so they can be used for future laboratory development. One of the laboratories that produces many works is a print and illustration laboratory. In this laboratory, it accommodates several subjects including Illustration, Graphic Method, and Illustration Media. Many products that have been produced include Visual Design and Souvenir Products, popup books, profile books, sign system, etc. While several research titles that have been produced include the UPN "Veteran" Jawa Timur as the Identity of the Defending State Campus (2017), Sign System in the UPN "Veteran" Jawa Timur Environment (2016).

In the Print and Illustration Laboratory the Visual Communication of Design program studied communication concepts and creative expressions, techniques and media by utilizing visual elements to convey a message for a specific purpose (the purpose of information or the purpose of persuasion that is influencing behavior), developing visual language forms (playing pictures), processing messages (playing on words) for social or commercial purposes, from individuals or groups addressed to other groups.

However, there are obstacles faced by Print and Illustration Laboratories as well as several other laboratories that support to be able to produce products that can be commercialized, namely the lack of tools, facilities and infrastructure. There are currently some equipment that is damaged and cannot function optimally, for example printers in the print lab and illustrations that have been damaged, cameras in the recording media lab that have moldy lenses and the absence of display cabinets in the design lab so that the study program cannot store student work products. Sometimes in the process of making these products for example making souvenirs during assignments, students print off campus so that it requires quite expensive costs and the quality of results is not good. With the existence of these production support tools, it is expected that laboratory performance will be more 
optimal and the products produced can be better and can be commercialized. The following is a list of commercialization products that can be produced along with the tools needed, including:

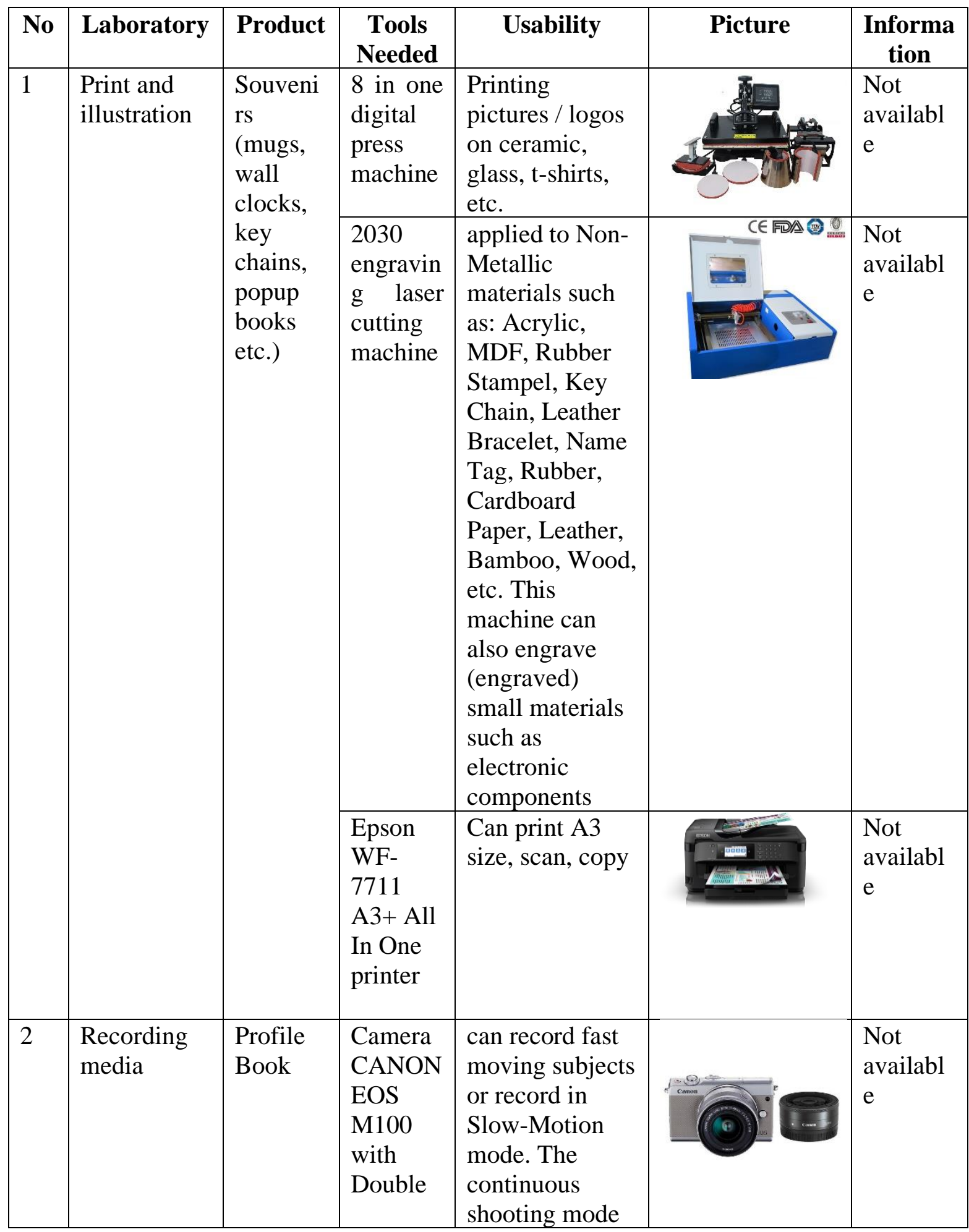




\begin{tabular}{|l|l|l|l|l|l|l|}
\hline & & $\begin{array}{l}\text { Lens } \\
\text { Grey } \\
\text { frames per } \\
\text { second, and can } \\
\text { be up to 6.1 } \\
\text { frames per } \\
\text { second with AF } \\
\text { Lock }\end{array}$ & $\begin{array}{l}\text { can reach 4.0 } \\
\text { fark }\end{array}$ & & & \\
\hline 3 & Design & $\begin{array}{l}\text { Story } \\
\text { Book }\end{array}$ & $\begin{array}{l}\text { Display } \\
\text { cabinets } \\
\text { DETOL } \\
\text { F }\end{array}$ & $\begin{array}{l}\text { Can store } \\
\text { student work } \\
\text { products } \\
\text { Glass } \\
\text { door } \\
\text { cabinet, }\end{array}$ & & $\begin{array}{l}\text { Not } \\
\text { availabl } \\
\text { e }\end{array}$ \\
\hline
\end{tabular}

Table 1. Equipment needed by the Laboratory

With the holding of some of the tools and facilities above, it is expected that the print and illustration laboratories assisted by several other laboratories in FAD can produce work products from students that can be commercialized and have the character of defending the country so that they can be the pride of FAD in particular and UPN "Veteran" Jawa Timur in general. In realizing this desire, the laboratory is assisted by the presence of partners. Partners in this case are Greenroom which is engaged in printing souvenirs and merchandise. In the field of printing Greenroom has not long been explored, so it needs assistance in both production and business management. Sales of souvenir products in 1.5 years are still relatively small, this is because there are a number of tools and designs that are less than optimal and the ability of design and printing souvenirs who have not received training. With this activity it is hoped that there will be an increase in production from partners and automatically increase Greenroom revenue. 


\section{METHODOLOGY}

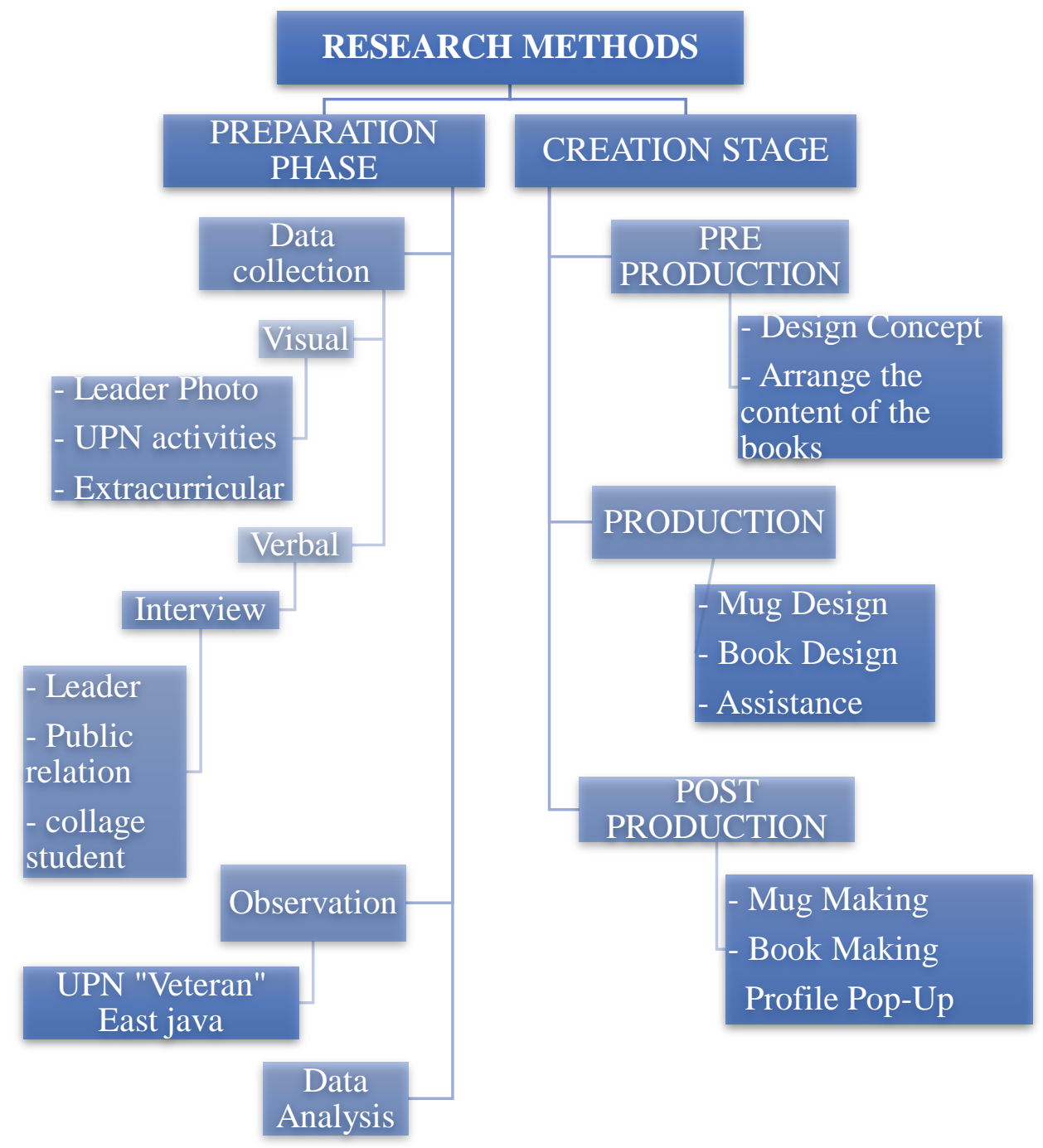

Table 2. Methodology

This research outlines through two stages, namely: (1) the preparation phase; (2) creation stage. The preparation phase includes data collection and data analysis. While the stages of creation include preproduction, production and postproduction.

a) Preparation Phase

1. Data Collection

The data collection stage has several stages that must be carried out, among others:

- Observation, at the observation stage is carried out to observe the conditions and situation of the location for shooting photographs. 
- Verbal, at this stage an interview was conducted to the Rector, Public Relations of UPN "Veterans" Jawa Timur, Dean, Head of The Study Program. The results of this interview were used to complete the profile book of UPN "Veteran" Jawa Timur.

- Visually, at this stage the researcher will take a photo of Pak Rector of UPN "Veteran" Jawa Timur, Vice Chancellor 1,2, 3, UPN "Veteran" Jawa Timur activities, extracurricular activities, etc. the results of the photo are used for visual book profile.

2. Data Analysis

Data analysis is the stage that must be done after the data has been collected.

This is done to sort and sort the data starting from the priority.

b) Creation Stage

1. Pre Production

- Prepare the tools needed to support the manufacture of products including press machines, laser cutting, cameras, A3 printers and display cabinets.

- Design Concepts, making design concepts for manufacturing products

- Arrange the contents of the profile book, compile the contents of the profile book from the data that has been collected.

2. Production

- Designing products including mugs and profile books.

3. Post Production

- Execute the product using the tools that have been purchased

\section{RESULTS AND DISCUSSION}

Product definitions are purchased objects that serve as a reminder of a particular experience, are produced commercially and are often universally linked to tourism. (Prakosa \& Cheon: 2013).

From the above understanding, this research becomes clear, that the products produced by print laboratories and illustration of FAD UPN "Veteran" Jawa Timur are indeed very necessary because there are many products that can be produced by students in this laboratory. The product can be used as a promotional media, as well as a reminder (reminiscence), which has artistic value in introducing the campus of UPN "Veteran" Jawa Timur to a wider area. Here are some examples of products from print and illustration laboratories that can be commercialized:

1. Mug Package

Coffee / tea cup package consisting of a cup mat, a cup, a pen and a note. 


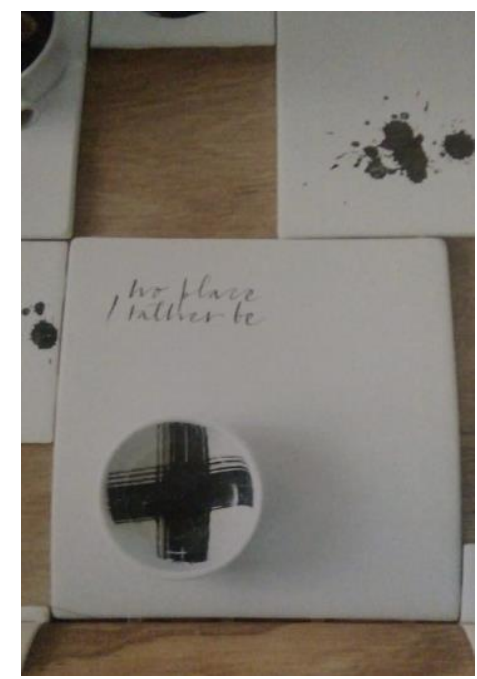

Picture 1. Mug Design example

2. UPN "Veteran" Jawa Timur Profile Book

The profile book of UPN "Veteran" Jawa Timur which consists of background, history, vision and mission, faculties, departments, study programs. Student activities, extracurricular activities, community service, and research. All explanations include photos and innovative layout designs. The profile book can be used as a memento for the guests / visitors of UPN "Veteran" Jawa Timur. And can be stored for a long time.

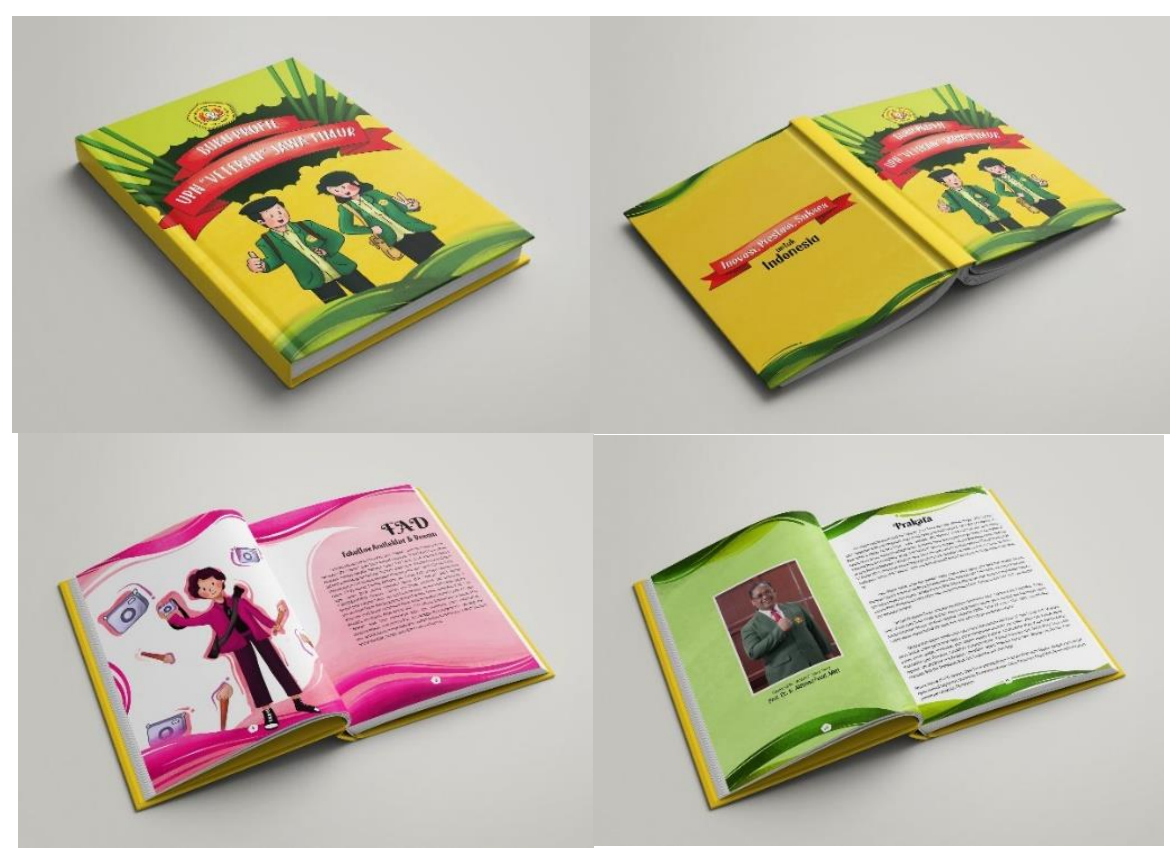

Picture 2. Profile Book Design of UPN "Veteran" Jawa Timur. 
The output that will be generated in this research is:

1. Souvenir Products

2. IPR design products and souverir for the UPN "Veteran" Jawa Timur

3. International seminar publication

\begin{tabular}{|c|l|l|}
\hline No & \multicolumn{1}{|c|}{ Output } & \multicolumn{1}{c|}{ Achievement Indicator } \\
\hline 1 & Appropriate Technology & Souvenir design \\
\hline 2 & Product & $\begin{array}{l}\bullet \text { Mug Package } \\
\text { Profile Book of UPN "Veteran" } \\
\text { Jawa Timur }\end{array}$ \\
\hline 3 & IPR Industry product design & registered \\
\hline 4 & $\begin{array}{l}\text { Scientific texts in magazines with } \\
\text { ISSN }\end{array}$ & Available \\
\hline
\end{tabular}

Table 3. Output research

\section{CONCLUSION}

In addition to concluding remarks, this part also presents recommendation as well as implication of the finding as a whole, either intended to broaden methodological realm or to develop a theoretical framework, as such that it outreaches the users from broader societies. Moreover, it can also be added the prospect of further studies into the next (based on result and discussion).

\section{ACKNOWLEDGMENT}

Thank you to all those who have helped smooth the research. Thank you to the UPN "Veteran" Jawa Timur LPPM, UPN "Veteran" Jawa Timur Chancellor, UPN "Veteran" Jawa Timur Dean, UPN "Veteran" Jawa Timur Lecturers, UPN "Veteran" Jawa Timur Staff, UPN "Veterans" Jawa Timur Students.

\section{BIODATA}

Masnuna, ST., M.Sn is a lecturer of Communication Visual of Design Dept on UPN "Veteran" Jawa Timur, Surabaya, Indonesia. She has a research interest in Illustration.

Lily Syahrial, ST., MT is a lecturer of Architectur Dept, UPN "Veteran" Jawa Timur, Surabaya, Indonesia.

Dyan Agustin, ST., MT is a lecturer of Architectur Dept, UPN "Veteran" Jawa Timur, Surabaya, Indonesia. 


\section{REFERENCES}

\section{Books}

Nurnitasari, Aprianita and Sofiyah. (2009). Menjadi Pengusaha Setelah Di-PHK. Yogyakarta : Indonesia Tera.

\section{Article in a Scientific Journal}

Prakosa, S., Cheon, H.,2013, Thai tourists' souvenir shopping experience in Korea,Asia Marketing Journal 15(3),15-29., ISSN: 1598-7868. 